NEW LITERARIA-

An International Journal of Interdisciplinary Studies in Humanities

Volume 3, No. 1, January-February, 2022, PP. 141-147

ISSN: 2582-7375

DOI: https://dx.doi.org/10.48189/nl.2022.v03i1.016

www.newliteraria.com

\title{
Reconstructing the 'Witch' Image in Fairy Tales: Exploring Katherine Arden's Winternight Trilogy
}

\author{
Jasna Jalal
}

\begin{abstract}
Fairy tales, a genre that offers an enchanted adventure and depicts the struggle between good and bad forces, has fascinated and entertained adults as well as children since time immemorial. Witches, the antagonist of most of the fairy tales are portrayed as the epitome of evil: wicked and scary old crones who abduct and devour children. Contemporary fairy tales, in contrast to conventional ones, offer an entirely different portrayal of witches as young and courageous women signifying virtue. The witches in fairy tales who were pictured as a threat to the heroine or hero are now presented as central characters around which the entire plot revolves. This paper attempts to examine how such a shift happened by analysing Katherine Arden's Winternight Trilogy, a fairy tale consisting of novels The Bear and the Nightingale (2017), The Girl in the Tower (2018) and The Winter of the Witch (2019) to understand the relevance of contemporary fairy tales in reconstructing the image of witch from a havoc creator to a saviour. It also seeks to study how the depiction of witches in fairy tales has evolved from a marginalized position to a central figure over time and its significance in the present scenario.
\end{abstract}

Keywords: Fairy Tale, Witch, Virtue, Evil, Reconstruction.

\section{Introduction}

Stories and the act of story-telling are universal and fairy tales signify the type of literature or first stories everyone encounter as children that offer both fun and adventure. These tales are perceived by children either in oral form, read or told by parents and others, or visually apprehended through movies or reading of books. The tradition of fairy tales can be traced back to centuries when tales were passed orally from generation to generation before their circulation in written form. The earliest written edition of fairy tales in Europe is Giovanni Francesco Straparola's The Facetious Nights of Straparola or The Night of Straparola published in sixteenth century containing seventy four tales. This work influenced other writers such as the French author Charles Perrault to publish his book of fairy tales titled Stories or Tales from Past Times in 1697 and this work later influenced the German version of fairy tales published by Brothers Grimm. Wilhelm and Jacob Grimm published the first edition of a two-volume collection of fairy tales in 1812 as Children's and Household Tales. Brothers Grimm never wrote any of the tales included in their volume but compiled the stories that had been circulating throughout Europe for centuries which had been supplied to them by their relatives and friends. However, their version received a wider acceptance and acclaim among readers than previous editions of fairy tales and was followed by other writers such as Hans Christian Anderson and George MacDonald who wrote fairy tales in their own ways making alterations. 


\section{Fairy Tales}

Fairy tales impart certain seminal aspects through the stories. They often begin with the idea of 'once upon a time' and proceed to represent the conflict between good and evil forces where the former triumphs over the latter thereby proceeding to a happy ending of the tale with a moral note. Characters such as queens, princes, giants, dragons, dwarves, ogres, princesses and talking animals form chief aspects in fairy tales along with magical elements such as talking mirror as in "Snow White", frog that turns into a Prince as in "The Frog Prince", pumpkin that turns into a carriage as in "Cinderella", and giant that lives up a beanstalk as in "Jack and the Beanstalk."

A virtuous protagonist and a malevolent antagonist form an essential trope in fairy tales. Often the antagonists in fairy tales are evil stepmothers as depicted in "Cinderella" and "Snow White", or witches as presented in "Rapunzel", "Hansel and Gretel" and "The Little Mermaid". They use power or magic to control and destroy everyone for personal gain and are severely punished by death at the end of the tale. Sheldon Cashdan (1999) says, "Western fairy tales, particularly those of the Grimm brothers, subscribe more to the biblical principle of an eye for an eye, a tooth for a tooth. One must, in the last analysis, pay for one's sins. Only by destroying the evil in the story can justice be served and undesirable tendencies in the reader mastered" (Cashdan, 1999, p. 56).

\subsection{Significance of Fairy Tales}

As Jack Zipes (2012) quotes the words of Vincenzo di Kastiaux, "Fairy Tale signifies belief in the supernatural, not the suspension of belief. We all believe in the extra-ordinary of Once Upon a Time. We need to believe. We all dream and breathe through our Tales" (Zipes, 2012, p. 21). Fairy tales form part and parcel of humanity. Even though adults too also enjoy fairy tales, they impart an inseparable role in the lives of children since the early stage in shaping their character, behaviour and outlook towards the real world.

Fairy tales have an intense role in the emotional development of children as it guides and assists them in addressing issues in real life when the imaginative, creative world acts as a realm to the concrete world of life experiences. They render children a means to address their unexpressed thoughts, emotions and confusions thereby allowing them to identify with them. F. Andre Favat (1977) suggests that "Children's turning to the tale is no casual recreation or pleasant diversion; instead, it is an insistent search for an ordered world more satisfying than the real one, a sober striving to deal with the crisis of experience they are undergoing" (Favat, 1977, p. 62).

Fairy tales also present an existential dilemma in a simplified way so that the children imbibe it in an intense manner including the images that accompany the stories. The child unconsciously internalises such symbolic depictions and often associate the self with the good character. Fairy tales also affirm the fact that struggles or difficulties are inevitable aspects of existence, the need to tackle obstacles and emerge victorious through moral affirmation. The moral message conveyed by the tale has an everlasting impact upon the unconscious mind of the child in addressing the future ordeals as a happy ending is ensured by the tales.

Fairy tales are, in fact, future oriented tales that mould and shape the young developing minds. It is significant as a work of art that has comprehensible as well as symbolic meanings. Paul V. Trad, in his work The Preschool Child: Assessment, Diagnosis and Treatment discusses the study conducted by Scarlett and Wolf in examining the influence of fairy tales 
upon children. According to them, fairy tales and real life overlap as well as intrude upon one another.

\subsection{Depictions in Fairy Tales}

Fairy tales, though perceived as symbolic representation of life, are also criticised as not rendering the true picture of life as it at times present far from reality or fearsome or cruel episodes which upset children and can generate serious consequences in shaping their character. They also play a relevant role in generating sexist and misogynistic notions in understanding as a well as internalising the concepts of gender, agency, freedom of choice and beauty. Conventional female stereotypes in fairy tales are limited to either good mothers, good wives or good daughters who are submissive or wicked witches and stepmothers who are deviant women. Male characters are often portrayed as powerful, authoritative, wealthy, courageous and handsome heroes who rescue the damsels in distress and offer a hand to them in marriage. Jack Zipes (2006) points out the words of women who were part of the Merseyside Women's Liberation Movement in Liverpool to indicate the role of the patriarchal symbolic order in perpetuating rigid notions of gender and sexuality through fairy tales. He states, "Fairy tales are political. They help to form children's values and teach them to accept our society and their roles in it. Central to this society is the assumption that domination and submission are the natural basis of all our relationships" (Zipes, 2006, p. 179).

Modern and postmodern depictions of fairy tales in forms such as stories, movies and animations stand in contrast to these conventional presentations and they are more emancipatory in conveying gender roles and practices. Edith Nesbit's The Last of the Dragons published in 1899 can be noted as an earliest attempt in deconstructing the traditional trope of fairy tales. The princess in the tale asks her father why she is supposed to be rescued from the dragon by a prince whom she regards as silly little boy and the author brings a change in the fairy tale plot where the princess and the prince together decide to tame the last dragon in Cornwall. Nesbit also presents the prince as a doubting, unheroic one who fears of getting killed by the dragon while the princess as a brave and confident young lady.

In “The Spell of the Magician's Daughter" (1902) by Evelyn Sharp, Firefly, the youngest of four daughters of a magician stands as an outstanding character who decides not to master magic and to become a witch unlike her sisters. At the end of the tale, the prince marries her not because of her beauty, but because of her cleverness, perseverance and assertion of her dignity as a woman. Jeanne Desy's "The Princess Who Stood on Her Own Two Feet" (1982) also depicts a princess who is a witch and refuses to marry a Prince who fails to respect and accept her virtue.

These revisionist attempts in fairy tales can also be placed in parallel with feminist reworking of fairy tales. Anne Isbella Thackeray Ritchie in Bluebeard's Keys and Other Stories (1873) rewrites nine fairy tales and reinterpret them in a way that suits the time. Anne Sexton's Transformations (1971) also offers a collection of confessional poetry based on the revision of classic fairy tales by Brothers Grimm. Angela Carter, inspired by the fairy tale collection of author Charles Perrault, reworked the tales focusing on gender politics in her work The Bloody Chamber and Other Tales (1979). Jack Zipes' Don't Bet on the Prince: Contemporary Feminist Fairy Tales in North America and England (1986) and Barbara Walker's Feminist Fairy Tales (1996) portray women characters in tales as controllers of their own fate rather than being submissive, silent individuals.

Such feminist representations can be regarded as a fight against the so far accepted and followed gender roles and behaviours. It is also an act of rejecting the patriarchal conventions and norms thereby deconstructing the systems of power and structures of oppression towards a female-centric one. According to Jack Zipes (2006), "The traditional stories are transfigured 
so that their repressive substance is subverted. The reversal of form, characters and motifs is intended to expand the possibilities to question the fairy tale discourse within the civilizing process (Zipes, 2006, p. 181).

\section{Witch in Literature}

Witches have been part of literature for centuries and it dates back to classical literature from Homer's Odyssey, Ovid's Metamorphoses, and Horace's Epodes which depicted them as evil beings indulged in malignant practice creating havoc. The writings of the Middle Ages, mainly demonological works written between 1435 and 1689, such as Joanne Nider's Formicarius or The Ant Hill (1435) and Malleus Maleficarum or The Hammer of Witches (1486) by Heinrich Kramer and Jacob Sprenger also played a significant role in shaping the popular perception of witches with extreme misogynistic notions. Daemonologie (1597) by King James VI of Scotland (James I of England) further projected witches as evil beings and shaped the image of witches for later writers like William Shakespeare (Macbeth) and Thomas Middleton (The Witches).

The twentieth century heralded a revolutionary change in the depiction of witches through the genre of fantasy literature by the works of L. Frank Baum's The Wonderful Wizard of Oz (1900), and later by Roald Dahl's The Witches (1983) and J. K. Rowling's Harry Potter series (1997-2007) which caricatured witches differently and brought a Witch Wave in popular culture resulting in the film adaptations of these works. The popular image of the witch too has undergone several changes in various forms of media as a result and fairy tales are a significant category that marked the change in the portrayal of witches.

\subsection{Witch in Fairy Tales}

In fairy tales, witch is used a powerful symbol and reflection of the wicked inner conscience of human self. Witch depicts the archetypal deviant woman that denounces the norms of patriarchy and exercises the privileges of freedom, autonomy and outspoken nature often enjoyed by men. A witch thus challenges the conventional order of male-centrism by not confirming to societal expectations. "In a word, the portrayal of witches and other "evil women" in the tales perpetuates the stereotypical notion of the witch. The tales - didactic, cautionary and entertaining in nature - are conventional, conservative, and paternalistic. The tendency to depict a malevolent maternal figure that explains the formulaic existence of evil stepmothers/witches cannot be more appropriate for such patriarchal and sexist tales" (Shen, 2008, p. 21).

Witches, in fairy tales, are depicted as unattractive, scary old crones living in the outskirts of human dwellings or forests as an outcast and engaged in malicious actions harming others. In certain fairy tales such as "Hansel and Gretel", witch exhibits cannibalistic tendencies such as deluding and devouring children in spite of evil inclinations. She attracts children with her house made of confectionaries and bread to feast upon them. In "Rapunzel", the witch imprisons the heroine in a room at the top of the tower and hides her from the rest of the world to satisfy her selfish motives. The Sea witch in "The Little Mermaid" is presented as a ruthless creature, residing in underwater swamp surrounded by sea serpents and toads. Her home is built by bones of human beings. She takes away the mermaid's voice to render her a potion that ensures mermaid a pair of legs.

Witches always act as an external threat to hero or heroine in fairy tales and their elimination or eradication is part and parcel of fairy tales to affirm the victory of good over bad forces. Witch, in fact, acts as foil to protagonist in appearance, character and actions in fairy tales. 


\subsection{Witch in Winternight Trilogy}

The Winternight Trilogy by Katherine Arden consists of novels The Bear and the Nightingale (2017), The Girl in the Tower (2018) and The Winter of the Witch (2019). The trilogy is set in medieval Russia and it blends Russian myths and culture to generate an evocative world. Vasilisa Petrovna, called as Vasya, the seventeen-year-old protagonist of the fiction who is the daughter of boyar Pyotr Vladimirovich and grand-daughter of the witch Tamara, reconstructs the stereotypical notion of witches in fairy tales and stands as an epitome of post-modern witch. The characters of fairy tales which usually belong to a fixed set of norms and conventions are dismantled by Arden through the trilogy.

Vasya hails from Lesnaya Zemlya, the "Land of the Forest" (Arden, 2017, p. 416) and the setting of the novels is a typical patriarchal society where norms are defined and propagated by men. Being a young woman, her choices in life are limited to two as either marriage or a life in convent. But she chooses a third path, the path of magic and life as a witch thereby challenging the expected gender roles. Arden also includes aspects such as demons, spirits and invaders along with the significance of family bondage to strengthen her heroine as a true specimen of contemporary fairy tale protagonist who is a witch as well as saviour of the community.

Vasya contrasts the conventional figure of beautiful princess in fairy tales waiting for a charming prince to rescue from dilemma while she creates a path of her own, the path of witchcraft inherited from her grandmother, to take charge of her own life by transcending the limits. In contrast to the witches in traditional fairy tales, Vasya is young and forms part of a larger household than being an outcast pushed to the fringes. She emphasises a shift in the witch's marginal position to a central figure that regulates the entire plot of the fiction as a protagonist instead of being an antagonist.

Vasya replaces the wicked, vicious image of a witch in fairy tales to a virtuous, caring and kind witch who acknowledges the forces of nature and spirits in pagan tradition along with her Christian faith to ensure the existence of humanity. She is religious, visits church alongside paying homage to old magic which is frowned upon by the church. She operates as the connecting link between the real world and the magical world to ensure their coexistence. She demands Dimitri, the Grand Prince of Moscow, not to condemn witches and allow people to have both the faiths by sharing the world together.

Vasya cherishes her life as a witch, protects her family and prepares to sacrifice her life for their safety when she says, "I am not afraid to die" (Arden, 2019, p.147). She emerges as the saviour of Moscow from Kaschei the Deathless, an evil sorcerer and bandits known as Tatars to claim the epithet "Vasili the Brave" (Arden, 2018, p. 152). She saves girls stolen from the villages to be sold in the slave market and safeguards the burnt villages as well as its people from harm.

Vasya, on the one hand, holds on strictly to what she is, and at the same time, frames her own rules for fulfilling a life of freedom and satisfaction. She says, "I want freedom" (Arden, 2018, p.233) and adds, "You cannot send me to a convent; I am not going to marry anyone. I cannot be a lord in Moscow, but I will not be a maiden. I am going away" (Arden, 2018 , p. 241). Being a girl, her longing to explore the world restricts her movement, so she chooses to cut her hair and dress as a boy. Morozko, the frost demon says, "The world is not kind to girls alone" (Arden, 2018, p. 62) as a warning to Vasya thereby reinforcing the hidden dangers.

Vasya poses a threat to the priest Konstantin Nikonovich, who madly desires power and worldly pleasures. He calls her the green-eyed witch and judges her alluring and tempting him. His yearning to possess her and her denial forces him to attack her publicly accusing of 
black sorcery and attempts to burn her at the stake, a fate destined for all witches. Her horsemanship, desire to possess weapons and warrior like qualities add to her merit as a witch.

Arden also brings a ground breaking change in the presentation of witches through her trilogy where she depicts Vasya's niece, Marya also as a witch possessing powers despite being a child. Marya too desires freedom and exhibits qualities of boldness and fearlessness as Vasya. She acts as a strong force in binding together the human world and the spiritual world together with Vasya. Marya's mother, Olga adheres to patriarchal norms and fears of her daughter' reputation by insisting to stay in the tower and hide her powers from the outer world.

Vasya also presents an alteration in the depiction of other witches in the novels where her great-grandmother and her grandmother who were witches, abandoned from the mainstream society and forced to live a secluded life in the forest. She, on the other hand, lives as part of the family and society where her presence and actions become relevant for the survival of everyone. Vasya surfaces up as the determiner of everyone's fate.

\section{Conclusion}

Fairy tales are a means of celebrating life through elements of fantasy and imagination. They act as instruments in imparting stories and lessons to children alongside offering them creativity and entertainment, improves vocabulary and problem-solving capacity and contemplates inner conflicts. Though they are framed within a conservative structure and plot, they always amuse the readers and stand timely.

Katherine Arden's Winternight Trilogy, a fairy tale consisting of novels The Bear and the Nightingale (2017), The Girl in the Tower (2018) and The Winter of the Witch (2019) reconstructs the conventional image of witches in fairy tales to redefine and recreate them in a new light. The 'witch' emerges as an accommodating protective figure rather than being an element to be eliminated from the social sphere.

This transformation in depiction can also be perceived as an attempt to reconcile the so far marginalised categories of traditions and practices such as witches and witchcraft to receive acceptance. The advent of witch narratives in forms such as autobiographies and memoirs also marks a significant point where the so far hidden or forbidden subjects in literature as well as society such as witchcraft are coming to the forefront and asserting their position through literary forms such as fairy tales in an entirely different perspective.

Contemporary fairy tales such as Katherine Arden's Winternight Trilogy opens up the idea similar to that of the two faces of a coin where the witches in fairy tales too can be good in thoughts and deeds. Arden also attempts to throw light upon the relevance of witchcraft and witches in the present scenario as an alternate spiritual path to mainstream faiths that offers solace in harmony with forces of nature as Vasya signifies in the novels. Vasya can, thus, be regarded as the true embodiment or figure that envisages modern witchcraft as she uses her power and the elements of nature to empower herself as well as the community.

\section{Reference}

Arden, K. (2017). The Bear and the Nightingale. London: Del Rey.

Arden, K. (2018). The Girl in the Tower. London: Del Rey.

Arden, K. (2019). The Winter of the Witch. London: Del Rey. 
Bottigheimer, R.B. (2009). Fairy Tales: A New History. Albany: Excelsior Editions.

Cashdan, S. (1999). The Witch Must Die: The Hidden Meaning of Fairy Tales. New York: Basic Books.

Danilewitz, D. (1991). "Once upon a time..... The Meaning and Importance of Fairy Tales." Early Child Development and Care, $75 \quad$ (1), 87-98. http://dx.doi.org/10.1080/0300443910750104

Favat, F. A. (1977). Child and Tale :The Origins of Interest. Urbana: National Council of Teachers of English.

Shen, Q. (2008). "Feminist Redemption of the Witch: Grimm and Michelet as NineteenthCentury Models." Focus on German Studies, 15, 19-33. http://repository.brynmawr.edu/german_pubs/11

Trad, P.V. (1989). The Preschool Child: Assessment, Diagnosis and Treatment. Hoboken: John Wiley \& Sons.

Walker, N.A. (1995). The Disobedient Writer: Women and Narrative Tradition. Austin: University of Texas Press.

Zipes, J. (2 ${ }^{\text {nd }}$ ed.). (2006). Fairy Tales and the Art of Subversion: The Classical Genre of Children and the Press of Civilization. Routledge.

Zipes, J. (2006). Why Fairy Tales Stick: The Evolution and Relevance of a Genre. New York: Routledge.

Zipes, J. (2012). The Irresistible Fairy Tales: The Cultural and Social History of the Genre.

Princeton: Princeton University Press.

\section{Bio-note}

Ms. Jasna Jalal is a research scholar in the department of English, T.K.M college of Arts and Science, Kollam University of Kerala.

Email Id: jasnajalal376@gmail.com 